\title{
Issues and Perspectives on Nigeria's International Economic Relations
}

\author{
Dele Seteolu \\ Lagos State University, Lagos, Nigeria
}

\begin{abstract}
The integration of Nigeria's economy into the international capitalist system was a defining context of its international economic relations. The country was integrated into the international capitalist system as dependent, peripheral, neo-colonial formation. The nature of external debt, foreign direct investment and economic policy choices reflect the influence of the global north on Nigeria's international economic relations. The management of the national economy and external economic relations respond to the logic of externally defined economic policy choices. This article examines strands of Nigeria's international economic relations and it offers positions to mediate the country's peripheral status. The article prescribes state-led development paradigm and assertive state to address the country's underdevelopment and actualizes robust and assertive foreign economic relations. The state-led development paradigm negates the neo-liberal policy and its preference for state withdrawal. The article insists that the state should play leading role in the development process to reverse the country's underdevelopment and reequip its foreign economic relations.
\end{abstract}

Keywords: neo-liberal, neo-colonial, dependent, peripheral, state-led development paradigm, assertive state, global north, external debt, foreign direct investment (FDI)

\section{Introduction}

The political and economic turfs are not separate and independent entities in international politics. The economic sub-structure and the political superstructure are inter-related and mutually reinforced in a sense that reflects the contending forces and power relations at the domestic level and international level. These contending forces and power centres defined the nature of international political and economic relations. The economic depression of the post World War II, the formation of the Breton Wood institutions, the cold war and its subsequent collapse, the formation of trade and economic blocs and the resultant multi-lateral relations defined the character of international economic relations that emerged.

The international political and economic system is, however, skewed in favour of the bourgeois capitalist states. The core capitalist states defined the structures and rules that constitute the bases of relationships at the international level. The developing and under-developed states became integrated into the global capitalist order as dependent and, therefore, unequal partners to the developed capitalist states. Nigeria's international economic relations should be understood in this context. The Nigerian state was integrated into the international economic and political system as peripheral, dependent, pseudo-capitalist formation, and these had implications for its foreign economic and political relations.

Dele Seteolu, Ph.D., Senior Lecturer, Department of Political Science, Lagos State University. 
The developed capitalist states and their correlating institutions assume the international economic and political architecture is interdependent and penetrating. The realities, however, negate this assumption of the dominant economic powers. The core capitalist states are the major holders of global resources; these economies dominate international trade and finance. The integration of developing states into the international capitalist system and the implementation of neo-liberal policy in developing economies reflects the hegemony of the mature capitalist states in the periphery and the unequal relations between the core capitalist states and developing states.

Nigeria's international economic relations exist within the unequal international capitalist system (Nwoke, 2000). The article discusses the major strands in Nigeria's international economic relations; these strands are the country's external debt, foreign direct investment (FDI) and the status of Nigeria within the international economic and political system. There are proffered options to reduce the country's dependent status and strengthen its external economic relations. The article relies on the radical political economic theory to interrogate the nature of the global capitalist system, its consequences for Nigeria's international economic relations and the options left to state actors to realize vibrant and result oriented foreign economic relations. This approach is preferred for its theoretical edge to expose the economic forces underlying the workings of the international capitalist system.

\section{Theoretical Framework}

The discontent with modernization theory in the 1950s led to new strands of thinking, which culminated in dependency theory. Frank (1967) in his analysis of postcolonial state has argued that classical development theories such as modernity are misleading since the theories fail to articulate the true relationship between the developed world and the poor regions of the world. To Frank, modernity distorts the truth about the motive of the developed countries on their former colonies. Brandt commission (1980) that was constituted by the United Nations in 1977 reported that development predicated on modernity had failed. Reid (1995) on modernity submitted thus:

The hope that faster economic growth "modernization" in developing countries by itself would benefit the broad masses of poor people has not been fulfilled and no concept of development can be accepted which continues to condemn hundreds of millions of people to starvation and despair.

In the analysis of the metropolis-satellite relationship, Le Roux in Tedros (1992) and Samir (1977) posited that since the development of the satellite could lead to the emergence of new dominant groups capable of appropriating surplus for themselves, there was an obvious need for the metropolis to determine the optimum rate of development of its satellite. The metropolis, therefore, determined the level and pace that the African region was to develop through the adoption and implementation of ineffective development policies and strategies. To Sunkel (1969), dependency is the explanation of the economic development of a state in terms of the external influences: political, economic and cultural on national development policies. Dos Santos Theotonio in Fann and Hodges (1971) offered the historical dimension of the dependency relationships thus: [Dependency is]... an historical condition which shapes a certain structure of the world economy such that it favours some countries to the detriment of others and limits the development possibilities of the subordinate economics... a situation in which the economy of a certain group of countries is conditioned by the development and expansion of another economy, to which their own is subjected. 
From the foregoing, the dependency theory examines the relationship between the developed and underdeveloped states especially the economic penetration of the latter by the core capitalist states. It concentrates on the external mechanisms of control exerted by the metro pole on the satellite state. This theory insists that the centre maintains the periphery in a state of underdevelopment for reasons of exploitation. It avers that underdevelopment is not inherent condition; rather it is the determined outcome of the historical relationship between the centre and peripheral state. The dependency theory posits that underdevelopment is a product of capitalist development; and it insists that underdevelopment would end when the capitalist system collapses (Amin, 1974; Wallerstein, 1974; Frank, 1969; Dos Santos, 1971).

The dependency theory focuses on the domestic experience of dependent states, the analyses of different types of export economy, the implications for class relations, and the forms of state that emerges. The analysis of class relations, which is determined through production outcomes, is essential aspect of this theory. The Comprador class underpins the coalition between the foreign bourgeois and indigenous classes in the exploitation and control of the satellite.

The Nigerian state was organically linked to the world capitalist system through colonialism and neo-colonialism for its exploitation and domination. The integration of Nigeria into the international capitalist system, therefore, conditioned its domestic and external behaviours. This article examines the implications of the country's integration into the global capitalist system for its external economic relations. It contends that Nigeria's foreign relations are the outcomes of the nature of the global and the place of the country within. The character of the international capitalist system, the status of Nigeria within the global capitalist structure and the consequences for its external economic relations are examined in the latter part of this work.

\section{The Political Economy of Nigeria's External Debt: Its Nature and Implications}

Nigeria's external debt is rooted in its integration into the international capitalist system; this economy was integrated to specialize in the export of cash crops to the industrial centres in the core capitalist states rather than invest in capital formation thereby pitching the country on the unfavorable side of international economic relations (Nwoke, 2000). The colonial economic system altered the production of food crop in colonial Nigeria and developed cash crop production for industrial Europe. The prices of agricultural commodities were determined by the industrial countries amidst the structuring of colonial economies as monoculture formations. The shift to oil economy further entrenched the vulnerable and dependent nature of the Nigerian economy. The oil glut of the 1980s, the discovery of North Sea oil and later Shale oil, the discovery of alternative energy sources to crude oil and conflict in Nigeria's Niger Delta region increased the vulnerability of the Nigerian economy. The decline in the price of crude oil in the late 1970s led the government to borrow from foreign creditors to address the balance of payment crisis and finance projects (Rahman, Adeola, Adeyemi, \& Tolulope, 2010, Romanus, 2014).

The World Bank and International Monetary Fund (IMF) had averred that the Nigerian economy was under-borrowed. The Nigerian government borrowed from the international capital market, but it had difficulty to offset the debt obligations (Olorode, 2014). The Nigerian state crept into external debt trap through the accumulation of debt arrears and commercialization of interest rates. The debt trap elicited plans to deal with the issue at the global level. The Brady, Bradley, Paris, London Clubs initiatives are responses of global capital to the external debt of developing countries. The Nigerian government failed to secure debt cancellation with the creditors and the rescheduling of its external debt was largely palliative since it secured the postponement 
of loan commitments amidst increasing external debt stock (Nwangwu \& Okoye, 2014, p. 45). Nigeria's external debt crisis heightened in 1985 when the creditors declined new lines of credit for the country to finance her imports (Onoh, 1989, p. 277). The external debt crisis became exacerbated through loans secured by the state governments from bilateral and multilateral organizations without the consent of the central authority.

The Fourth Republic was enmeshed in external indebtedness to the Paris Club of Creditors. The Obasanjo administration inherited debt crisis from his predecessors as a result of the inability to convert the borrowed funds for development purpose. Nigeria failed to offset debt owed to the Paris Club with its external debt stock at $\$ 28.273$ billion and its service cost at $\$ 1.71$ billion in 2000 (DMO, 2004). The diplomatic shuttle of former President Obasanjo to secure foreign debt relief barely altered the country's debt profile as the stock of external debt increased from $\$ 28.347$ billion in 2001 to $\$ 30.99$ billion and $\$ 32.91$ billion in 2002 and 2003 respectively (DMO, 2004).

The size of Nigeria's external debt was nearly $\$ 36$ billion in 2004 and $\$ 31$ billion of this debt was owed the Paris Club (85.82\%). The Paris Club granted relief to Nigeria in May 2005 through the cancellation of \$18 billion of the $\$ 36$ billion and it deferred payment of $\$ 12.4$ billion on arrears and buyback ${ }^{1}$. The Paris debt forgiveness is, however, perceived by Mansur Muhtar (2005) as a "second declaration of independence". To Muhtar, the country's external debt and the accompanying conditionality are instruments of imperialism.

The anticipated benefits expected to accrue from the partial debt cancelation in the Obasanjo administration were soon truncated by the international financial and economic crisis that started in 2009 . The crisis reflected in the decline in the price of crude oil from $\$ 147$ per barrel in July 2007 to $\$ 45$ per barrel in December 2008 and drop in the exchange rate of the Naira to the US dollars.

This article reiterates that the country's external debt reflects the distortions and imbalances in the global economic and financial system. Olorode (2014, p. 46) corroborates this assertion when he posits that the country's external debt reflects conspiracy between the West and the indigenous ruling class to plunder the economy to the disadvantage of the exploited and alienated working people, urban poor and rural peasants. The article contends that the foreign debt crisis will likely persist in Nigeria except its real sector is developed, local capital is strengthened and the economy is export-based. The import dependent nature of the Nigerian economy, dominance of foreign capital in the domestic economy, rentier nature of the state and rentier mentality of the governing class, crude oil based economy and its vulnerability to price fluctuations limit the capacity of the Nigerian state to reach autonomous economic and political decisions. The distortions in the economy are exposed when the country "consumes what it does not produce and produce what it does not consume". These disarticulations point at crises that hinder the capability of the state to exercise independent domestic and external decisions.

\section{Foreign Direct Investment: The Realities and Undercurrents}

FDI is rooted in the neo-liberal philosophy; this approach is in contradistinction to the protectionist measure that discourages FDI and develops local industries. The FDI is predicated on the assumption that it benefits developing countries through its spill-over effect on local capital, creating domestic competition and job opportunities, and stimulating the transfer of technology (Awolusi, 2012). The creation of Nigerian Investment Promotion Commission through Decree No. 16 of 1995 offered the impetus for the inflow of FDI into the country (Nwangwu \& Okoye, 2014). The Obasanjo civilian administration implemented the post

${ }^{1}$ Punch (Nigeria), 2005, 25 July, p. 25. 
structural adjustment program in 1999 as basis for the management of the economy and the attraction of FDI. The rubrics of post structural adjustment program included liberalization, privatization, commercialization, de-subsidization and deregulation. FDI, as embedded in the policy of liberalization, was a major concern of the Obasanjo administration to arrest the decline in the national economy, foster economic growth and economic development.

Meanwhile, the Nigerian economy attracted FDI as a result of its huge market size and natural resource endowment (Mojekwu \& Ogege, 2012, p. 191). The capital inflows emanated from South Africa, China, Singapore, Brazil and the developed capitalist countries; these foreign capital were invested in the telecommunications, housing and oil sectors. The September 11, 2001 attacks on the United States, however, led to $40 \%$ decline in FDI at the global level, but the inflow of capital to Nigeria dropped to $21 \%$ with the total inflow standing at $\$ 651$ million in $2002^{2}$. There was dramatic shift in 2003 when the inflow of foreign investment increased to $\$ 2.3$ billion, and it further increased at $138 \%$ to $\$ 5.31$ billion in 2004 . The size of foreign investment leapt at $87 \%$ to $\$ 9.92$ billion in 2005 and it was $\$ 9.6$ billion in 2007 as a result of the consolidation of banks two years earlier ${ }^{3}$. The consolidation exercise had attracted foreign banks and foreign investments into the Nigerian economy. The inflow of foreign investment into Nigeria declined in 2009 to $\$ 8.28$ billion and this was linked to the crises in the North-East and the Niger Delta region. FDI further declined in 2010 to $\$ 6.1$ billion (UNCTAD, 2011).

This article argues that FDI creates new contradictions in the hosting states including Nigeria. The textile industry in Nigeria, for instance, largely disappeared as a result of the liberalization policy. The local textile industries became exposed to unequal competitions of the foreign textile companies (Nmadu, 2008). The Nigerian state within the neo-liberal paradigm abandoned its superintendent role; this shift allowed foreign firms free reign in the economy. Consequently, the textile firm reputed as highly labour intensive and the oldest in Northern Nigeria was downsized with over 120,000 workers losing their jobs as a result of the divestment of government equity to private capital ${ }^{4}$.

The Nigerian state as a result of market reforms became less equipped to exercise supervisory role on the behaviour of foreign capital. The state lost control of the critical sectors of the national economy and it became pre-occupied with rent collection and minimalist role. The rentier nature of Nigerian state signifies the pre-occupation of state actors with the collection of rent on the export of crude oil. The state actors have shown least commitment to the development of the oil sector. The petroleum industry bill has been bogged by heavy politicization, which limits the plan to introduce greater accountability and probity in the oil sector and increase the role of indigenous capital in the oil sector. The minimalist nature of the Nigerian state is tied to the adoption of market reforms. The Yar'Adua, Jonathan and Buhari administrations sustained the neo-liberal policy in the economic space. The Buhari administration despite its 2015 presidential election promises of intervening in some sectors of the economy largely relies on market reforms in the management of the economy. The country's indebtedness to external creditors, heavy reliance on FDI to stimulate the economy, and the crude oil based economy with its attendant vulnerability to external forces will likely constrain the Buhari administration to pursue alternative economic agenda. The Nigerian economy reflects the assertive influence of the Breton Woods institutions on economic choices. The influence of creditor institutions on economic policy options

\footnotetext{
2 The Guardian (Nigeria), 2004, February 27.

3 Vanguard (Nigeria), 2008, May 19.

4 The Guardian (Nigeria), 2007, October 7.
} 
underpins the restricted capacity of state actors to reach independent economic decisions.

This article contends that the minimalist state character of the Nigerian state deepened under development and structural distortions in Nigeria. The article canvasses for assertive state rather than minimalist status to mediate underdevelopment and structural distortions in Nigeria. The Nigerian state should jettison uncritical embrace of market reforms and its philosophy; the purpose and implications of the reforms should be re-interrogated. It is argued in this article that the governing class will better engage foreign firms through the stronger presence of the Nigerian state in the organization and direction of the economy in a sense that reflect and respond to the country's strategic interests.

\section{Nigeria and the International Economic and Political Systems}

The contemporary international economic and political system crystallized at the end of the Second World War. The major victors of the war - the United States and the former Soviet Union - receded into military and ideological rivalries on the basis of bi-polar politics. The major world powers and their allies formed military and economic blocs to reflect these realities. The capitalist-based world order floated the IMF and World Bank to address the devastation in Europe following the Second World War. These international financial institutions, overtime, offered loan, development assistance, and prescribed neo-liberal reforms to Asia, Latin America and Africa to correct balance of payment and exchange rate crisis. The neo-liberal economic reforms are critiqued for the over emphasis on exchange rate stability to the detriment of developmental issues. The implementation of market reforms undermines rather than foster development. The protests and agitations on the social implications of market reforms in Nigeria and the growing social movement for new economic initiatives points at the crisis of neo-liberalism and its inherent contradictions.

Meanwhile, the world trading system was concretized through the Uruguay and Doha agreements to foster free trade and unhindered transfer of capital. The world trade organization (WTO) agreement replaced the Doha agreement as the premise of global trade. The thrusts of WTO are trade liberalization and the internationalization of finance capital. The negotiations that culminated in the WTO involved the core capitalist states; the underdeveloped and developing countries were not part of the power politics the agreement represents. The developed capitalist states, therefore, defined the international economic and financial architecture to reflect and sustain their strategic interests. The core interests of the underdeveloped and developing countries were not reflected in the international financial and economic order. The capitalist defined world economic order was built on specific regimes to articulate, foster and recreate the critical interests of the mature capitalist states.

The foregoing submissions on the nature of the international economic system challenge the assumption of equality of states and internationalization of resources. The international capitalist system is less equitable and internationalized in terms of the lopsided nature of the global economic order and the hegemony of developed capitalist states in the governance structure of the world economy. There is a contradictory character of the WTO when it canvasses trade liberalization for developing countries and the core capitalist states erect barriers against exports from developing states. This dysfunction in international trade relations signposts the skewed nature of the international economic system and the resultant struggle of developing countries for a new international economic and political order (Momoh, 2005, Oloruntoba \& Akinboye, 2013).

The Nigerian state adopted the IMF and World Bank conditionality and the structural adjustment program in the Babangida administration. This state, however, became weakened and vulnerable to foreign influences as 
a consequence of market reforms. The Nigerian state lost its legitimacy as a result of social dislocation of the weak social groups and conflicts occasioned by the implementation of neo-liberal reforms. The social backlash of neo-liberal reforms raises question on its suitability for the Nigeria state and economy. The closure of factories, job losses and mass unemployment, removal of subsidies on social services and the loss of social provisioning role by the state challenge the purpose of its social policy.

This article insists that considering the contradictions occasioned by the pursuit of neo-liberal reforms, the Nigerian state should be recreated to address human and social issues as the basis of political governance. The mass protests and disputations of the working people, peasants, artisans and urban poor on neo-liberal reforms in Nigeria suggest the preference for new economic policy and development agenda that responds to the challenge of human underdevelopment and economic backwardness. The United Nations African Alternative Framework to Structural Adjustment Program had been posed as alternative to orthodox Structural Adjustment Program as prescribed by the Breton Woods institutions. This alternative framework insists on human development as the fulcrum of economic plan. Similarly, the democratic developmental state is a repudiation of the neo-liberal state; it canvasses a strong role for the state as opposed to the decline of the state. The developmental state paradigm insists that the development crisis in the states undergoing market reforms requires a superintendent role for the state.

\section{Conclusion}

The article contended that Nigeria's international economic relations would be understood and better appreciated within the context of the lopsided international capitalist system. In other words, the nature of the international capitalist system defines the patterns of Nigeria's international economic relations. The specific nature of Nigeria's integration into the international capitalist framework ensured the dependent and peripheral status of the economy, its vulnerability to external influence, the disarticulation of the economy to serve the interest of foreign capital, and the imposition of foreign economic policies that are posed as endogenous economic choices. The country's foreign economic policy is constrained by these economic realities; the consequences are the absence of robust and highly articulate external relations.

The article examined the strands of Nigeria's international economic relations; the external debt portfolio, FDI and the country's status within the global economic order were analyzed. Nigeria's external debt crisis was explained in terms of the structure of the economy whereby the country "produced what it does not consume and it consumes what it does not produce". The article insisted that the FDI was not the linchpin of development for Nigeria. The Nigerian state, it argued, should develop local capital as the basis for autonomous economic development. This article doubted the capacity of the neo-liberal state in Nigeria to supervise the nature and quality of foreign capital penetration. The Nigerian state had been weakened by the adoption of neo-liberal reforms and consequently its capacity to superintend the inflow of foreign capital had been undermined. The Nigerian state should develop the capacity to supervise the behaviour of foreign capital in consonance with the country's strategic interests; this imperative will likely be achieved through alternative economic paradigms.

The state actors in Nigeria should rethink market policy, which reduces the capacity of the state to intervene in the country's development trajectory. The level of economic underdevelopment and social crisis requires state-led development paradigm to mediate the contradictions inherent in neo-liberal reforms and rebuild the economy to foster a critical role for the Nigerian state in regional and world affairs. 


\section{References}

Amin, S. (1974). Accumulation on a world scale. New York: Monthly Review Press.

Awolusi, O. (2012). Foreign direct investment and economic growth in Nigeria: A vector error correlation modeling. Journal of Research in Economics and International Finance, 1(3), 59. Retrieved from http://www.interesjournals.org/JRIBN

Central Bank of Nigeria Statistical Bulletin. (2007). Abuja: Central Bank of Nigeria Press

Central Bank of Nigeria Statistical Bulletin. (2008). Abuja: Central Bank of Nigeria Press.

Debt Management Office. (2004). Nigeria's external debt outstanding, 1983-2004. Retrieved from https://www.dmo.gov.ng/debt-profile/external-debts/external-debt-stock/1107-external-debt-outstanding-1983-2004/file

Dos Santos, T. (1971). The structure of dependence. In K. T. Fann, \& D. C. Hodges (Eds.), Readings in US imperialism (pp. 155-182). Boston: Porter Sargent.

Fann, K., \& Hodges, D. (Eds.). (1971). Readings on U.S imperialism. Boston: Porter Sargent.

Frank, A. (1967). Crisis in the third world. New York: Holmes \& Meier.

Frank, A. (1969). The development of underdevelopment. In A. G. Frank (Ed.), Latin America: Underdevelopment or revolution New York: Monthly Review Press.

Mojekwu, J., \& Ogege, S. (2012). Foreign direct investment and the challenges of sustainable development in Nigeria. Journal of Research in International Business and Management, 2(7), 191.

Momoh, A. (2005). In search of a new paradigm of world economic system. In A. Momoh (Ed.), Nigeria and the neo-liberal world economic system (pp. 3-14). Abuja: Friedrich Ebert Stiftung.

Muhtar, M. (2005, August 29). Debt relief: nothing to celebrate? Insider Weekly, Nigeria, 54-55.

Nmadu, T. (2008). Trade and declining worker rights in Nigeria's textile industry: 1997-2006. Forum on Public Policy, 9.

Nwangwu, C., \& Okoye, K. (2014). Management of external economic relations and the crisis of development in Nigeria. Global Journal of Arts Humanities and Social Sciences, 2(9), 45.

Nwoke, C. (2000). An overview of Nigeria's international economic relations. In R. A. Akindele, \& A. Bassey (Eds.), Selected readings on Nigeria's foreign policy and international relations (p. 75). NIIA Enlightenment Course Series, 1(1). Lagos: NIIA.

Olorode, O. (2014). Neo-liberal siege against Nigeria: In memory of Festus Ikhuoria Iyayi. Public Lecture delivered at the first anniversary of the transition of Professor Festus Ikhuoria Iyayi by the Academic Staff Union of Universities, University of Benin, Nigeria, on Wednesday, 12th Rovember. from http://www.scon.org.ng/neo-liberal-siege-against-nigeria-in-memory-of-festus-ikhuoria-iyayi/

Oloruntoba, S., \& Akinboye, S. (2013). Global governance of trade and economic development: Exploring opportunities in the South-South cooperation. Lagos: Nigerian Journal of International Affairs, 39(2), 93-113.

Onoh, J. (1989). Nigeria's external debts and the western clubs of creditors. In J. Ogwu, \& R. O. Omotayo (Eds.), Nigeria's international economic relations: Dimensions of dependence and change (p. 277). Lagos: NIIA.

Rahman, Y. B., Adeola, I. K., Adeyemi, O. M., \& Tolulope, A. O. (2010). Debt management and economic growth in Nigeria: performance, challenges and responsibilities. Management (Information Management), 12, 31-39.

Reid, D. (1995). Sustainable development: An introductory guide. London: Earth Scan Publication.

Romanus, O. (2014). External debt crisis, debt relief and economic growth: Lessons from Nigeria. European Journal of Business and Management, 6(33), 109-120.

Samir, A. (1977). The future of South Africa. Journal of Southern African Affairs, 2(3), 355-370.

Sunkel, O. (1969). National development policy and external dependence in Latin America. Journal of Development Studies, 6(1), 23.

Tedros, K. (1992). Moral philosophy and development. Athens: Ohio Press.

UNCTAD. (2011). World investment report. Retrieved from http://unctad.org/en/docs/wir2011_embargoed_en.pdf

Wallerstein, I. (1974). The modern world-system. New York: Academic Press. 